\title{
GC/MS characterization of the volatiles isolated from the wines obtained from the indigenous cultivar Feteasca Regalã
}

\author{
G. Câmpeanu², M. Burcea ${ }^{2, *}$, C. Doneanu1, I. Nămolosanu² and L. Visan ${ }^{2}$ \\ ${ }^{1}$ Faculty of Pharmacy, Department of Organic Chemistry, 6 Traian Vuia, Bucharest, Romania \\ ${ }^{2}$ Faculty of Biotechnology, University of Agricultural Sciences and Veterinary Medicine, Bd. Mãrãsti, \\ No. 59, 71329, Bucharest, Romania
}

\begin{abstract}
To improve the quality of the wine obtained from the indigenous cultivar Feteasca regalã , six selected yeast strains were used for wine making at a pilot scale. Their quality was established after routine chemical analysis, organoleptic control and gas chromatographic studies concerning volatile compounds. 52 compounds were identified using gas chromatography/mass spectrometry. Two strains from yeast species S. cerevisiae var. ellipsoideus and S. carlsbergensis were more valuable than commercial yeast usually used in this region.
\end{abstract}

Key words. wine - volatiles - gas chromatography/mass spectrometry - yeast - Feteasca regalã cultivar.

\section{Introduction}

At present there is a tendency in the countries with a developed wine making for selecting yeast strains appropriate for securing the authenticity in the specific climatic and edaphic conditions of the zone [17].

Romania has an old tradition for selection of some valuable yeasts originating from the most famous viticultural regions: Cotnari (for the indigenous cultivars: Grasã, Feteascã albã, Frâncusã), Iasi (Feteascã neagrã), Pietroasele (Grasã, Tãmâioasã româneascã), Drãgãsani (Tãmâioasã româneascã, Crâmposie, Negru vârtos), Odobesti (Galbenãa, Tãmâioasã româneascã), Dealu Mare (Pietroasa), Blaj (Feteascã albã) [12].

Starting from the necessity of selecting some valuable strains for improving the quality of young wines, the present research has been initiated, beginning with a region where such an investigation has not been performed up to now - the viticultural region Panciu. The aim was to improve the quality of the wine obtained from the indigenous cultivar Feteasca regalã.

The assessment of the most valuable strain has been performed by using some routine chemical methods, by gas chromatography/mass spectrometry and by organoleptic analysis. Their combination is absolutely necessary both for establishing the quality and for the identification of the compounds which confer aroma to the wine. The majority of these are found in relatively low concentrations $(\mu \mathrm{g} / \mathrm{L})$ [14] and for this, some techniques for volatile concentration has been used: wine distillation, the solvent extraction followed by extract concentration [9], volatiles concentration by sorbent extraction [8] or the analysis with consacrated systems for volatiles like headspace $[10,18,19]$, purge and trap
$[7,13,21]$ or solid phase microextraction [4]. Recently it was also proposed a method of injecting large sample volumes (up to $100 \mu \mathrm{L}$ ) of solvent extracts, without the concentration of the sample [15]. Many of this extraction techniques had already mentioned in some reviews dealing with volatiles constituents in wines [5,6,22].

In our studies we used the solvent extraction method. The organoleptic analysis of the wines has been performed by a commission of specialists, according to a methodology authorized on the national level.

\section{Experimental}

\section{Material and method}

Based on the natural genetic variability 15 yeast strains have been identified, belonging to the following species $\mathrm{S}$. oviformis (2 strains), S. cerevisiae var. ellipsoideus (3 strains), S. cerevisiae (3 strains), S. carlsbergensis (3 strains), S. italicus (1 strain), S. dairensis (1 strain) and Schizosaccharomyces pombe ( 2 strains). The prelevation of the biologic material was performed from various locations, from white and red grapes cultivated in the vineyards of Panciu. The identification of new isolated yeast strains was performed by using the classical microbiological methods as describe Lodder (1974) [11] and by multitest system API -20. In order to confirm the taxonomical identification of strains, a molecular technique has been used. The chromosomal DNA profiles were compared by pulsed field electrophoresis. [13] The TAFE - Beckman system for vertical gel electrophoresis was used and the chromosomal bands were visualised in U.V. light after ethidium bromide staining. Following some repeated enologic tests only 6 valuable

* Correspondence and reprints.

Work presented at In Vino Analytica Scientia, Bordeaux, 12-14 June, 1997.

Received July 28, 1997; revised December 11, 1997; accepted December 23, 1997. 
strains were selected (S. italicus -symbol $T_{1} ; \mathrm{S}$. cerevisiae var. ellipsoideus - symbol $T_{2}$; S cerevisiae - symbol $T_{6}$; S. carlsbergensis -symbol $T_{3} ; \mathrm{S}$. carlsbergensis - symbol $T_{4} ; \mathrm{S}$. carlsbergensis - symbol $T_{5}$ ). The control variant - symbol C, was a grape juice sample fermented with commercial yeasts used in the wine industry. They were used in wine making at a pilot scale from Feteasca regalã, a cultivar much extended in the region of Panciu. Healthy grapes yielded in 1995 have been used for obtaining a grape juice with $178 \mathrm{~g} / \mathrm{L}$ sugar and an acidity of $7,8 \mathrm{~g} / \mathrm{L} \mathrm{C}_{4} \mathrm{H}_{6} \mathrm{O}_{6}$. The climatic conditions of the year were considered normal for wine making. The routine analyses were accomplished: the alcoholic strength, free $\mathrm{SO}_{2}$, glycerol, the total and volatile acidity, the extract, the total $N$, according to the O.I.V. standards [23]. Volatile compounds were isolated by solvent extraction. $75 \mathrm{ml}$ of wine (containing internal standard IS 2-ethyl hexanol) were extracted with $15 \mathrm{~mL}$ solvent of pentane:dichloromethane (Merck, Darmstadt, Germany) 2:1 in a separation funel. Internal standard solution in absolute ethanol (Merck, Darmstadt, Germany) was previously prepared by adding $20 \mu \mathrm{L}(16.2 \mathrm{mg})$ of 2-ethyl hexanol to $4 \mathrm{~mL}$ of ethanol. From this solution $10 \mu \mathrm{L}$ were introduced in the wine sample. The solvent extract was placed in a $25 \mathrm{~mL}$ round bottom flask, then concentrated to about $1 \mathrm{~mL}$ under a gently nitrogen flow, at $25^{\circ} \mathrm{C}$. This $1 \mathrm{~mL}$ volume was further concentrated in a $2 \mathrm{~mL}$ vial under nitrogen flow to about $100 \mu \mathrm{L}$. From this solution $1 \mathrm{~mL}$ was injected in splitless injection mode.

\section{Chromatographic conditions}

A Carlo Erba GC 8000 gas chromatograph equipped with split/splitless injector was used. The separation of volatiles was achieved on a Supelcowax 10 fused silica capillary column (Supelco, Belefonte, USA) of $60 \mathrm{~m} \times 0.32 \mathrm{~mm}$ i.d. $\times$ $0.5 \mu \mathrm{m}$ film thickness. The oven temperature was programmed from $35^{\circ} \mathrm{C}(5 \mathrm{~min})$ to $250{ }^{\circ} \mathrm{C}(20 \mathrm{~min})$ with $5{ }^{\circ} \mathrm{C} / \mathrm{min}$. Hydrogen was used as carrier gas with an inlet pressure of $60 \mathrm{Kpa}$. The temperature of the injection port was $250{ }^{\circ} \mathrm{C}$ and the detector (FID) temperature was set at $260{ }^{\circ} \mathrm{C}$. For data aquisition a Spectra Physics DP700 integrator was used. Compounds identification was performed on the same capillary column installed in a FISONS INSTRUMENTS MD800 gas chromatograph/mass spectrometer equipped with split/splitless injector, using the same oven temperature program with helium as carrier. Data acquisition was performed with MassLab software for the mass range from 10 to 350 a.m.u. with a scan rate of $1 \mathrm{scan} / \mathrm{sec}$. The ionization energy was set at $70 \mathrm{eV}$. Recordered spectra were compared with NIST (National Institute for Standardization, USA) and Wiley ( $6^{\text {th }}$ edition 220.000 spectra) mass spectral libraries. Compounds identification was confirmed by Kovats retention time indices on Carbowax 20M capillary columns. Standard substances were also used for compound confirmation.

\section{Results and discussion}

By performing the routine chemical analyses and the degustation, the obtained results are presented in table I.

It is obvious that the obtained wines are normal, with composition indices that are characteristic to the zone and to the cultivar.

The alcoholic strength is placed around the same value (10.5\% vol. alcohol). The total nitrogen content ranges between 1.316 and $1.400 \mathrm{~g} / \mathrm{L}$.

As regards the glycerol, its values are placed between 5-6 g/L for the strains $T_{2}, T_{3}, T_{6}$, and even over $6 \mathrm{~g} / \mathrm{L}\left(T_{1}\right.$, $\left.T_{4}\right)$. The $T_{5}$ strain produces a glycerol content under $4 \mathrm{~g} / \mathrm{L}$.

The values of the dry extract recommend the wines in the range of the white table ones (15-17 g/L).

A clearer distinction between the yeast strains can be made by taking into account the values of the volatile acidity. As regards this parameter, we found out that the $T_{2}$ and $T_{3}$ strains produce a superior wine comparing to the control (0.36 mg/L $\mathrm{CH}_{3} \mathrm{COOH}$ comparing to $\left.0.4 \mathrm{mg} / \mathrm{L} \mathrm{CH}_{3} \mathrm{COOH}\right)$. The rest of the strains are producing a volatile acidity of a value over $0.5 \mathrm{mg} / \mathrm{L} \mathrm{CH}_{3} \mathrm{COOH}$.

Table I. The results of the routine chemical analyses and the degustation.

\begin{tabular}{|c|c|c|c|c|c|c|c|}
\hline & \multicolumn{7}{|c|}{ Wine identification* } \\
\hline & $T_{1}$ & Control & $T_{2}$ & $T_{3}$ & $T_{4}$ & $T_{5}$ & $T_{6}$ \\
\hline Total acidity (mg/L) & 6.75 & 6.6 & 6.3 & 6.7 & 6.37 & 5.92 & 5.45 \\
\hline $\begin{array}{l}\text { Volatile acidity } \\
\left(\mathrm{mg} / \mathrm{L} \mathrm{CH} \mathrm{CH}_{3} \mathrm{COOH}\right)\end{array}$ & 0.58 & 0.4 & 0.36 & 0.36 & 0.5 & 0.54 & 0.59 \\
\hline Alcohol \% vol as ethanol & 10.5 & 10.5 & 10.5 & 10.5 & 10.5 & 10.5 & 10.5 \\
\hline Solid substance $(\mathrm{g} / \mathrm{L})$ & 16 & 17 & 17 & 16 & 15 & 17 & 14 \\
\hline Glycerol (g/L) & 6.67 & 5.98 & 5.75 & 5.80 & 6.21 & 3.91 & 5.75 \\
\hline Total nitrogen content $(\mathrm{g} / \mathrm{L})$ & 1.316 & 1.344 & 1.372 & 1.330 & 1.400 & 1.358 & 1.372 \\
\hline Grades at degustation & 15.6 & 17.6 & 18.3 & 18.8 & 16.6 & 16.2 & 16.8 \\
\hline Classification & VII & III & II & I & VI & $\mathrm{V}$ & IV \\
\hline
\end{tabular}

*The wines received the symbol of the strain used for the grape juice fermentation. 
Generally, these values are concordant with the grades obtained by the organoleptic assessment (Place I - $T_{3}$; Place II - $T_{2}$; Place III - the control).

By using the chromatographic analysis (Fig. 1) 52 compouds were identified and their quantity was evaluated by the method of the internal standard. We point out that this analysis has been used for the first time in order to characterize the aroma of the wine obtained from the indigenous cultivar Feteasca regalã. In the table II are presented the identified compounds, the Kovats retention indices and the coresponding concentration calculated according to the formula:

$$
C_{\mathrm{x}}=(1000 \mathrm{~mL} / 75 \mathrm{~mL}) \mathrm{m}_{\mathrm{IS}} A_{\mathrm{x}} / A_{\mathrm{IS}}
$$

where:

$C_{\mathrm{x}}$ - represents the concentration of compound $\mathrm{X}$ in $\mu \mathrm{g} / \mathrm{L}$;

$m_{\mathrm{IS}}=40.5 \mu \mathrm{g}$, is the quantity of internal standard always added in wine before extraction;

$A_{\mathrm{x}}$ - is peak area corresponding for $\mathrm{X}$ compound;

$A_{\text {IS }}$ - is peak area for internal standard in each chromatogram.

It is noticeable that the $T_{2}$ and $T_{3}$ strains lead to the obtaining of a wine characterized by superior concentrations of some majoritary compounds resulted by the fermentation (2-pentanone, $n$-propanol, iso-butanol, isoamylic alcohols, ethyl caproate, $n$-amyl alcohol, ethyl lactate, 1-hexanol, ethyl caprylate, gamma butyrolactone, caproic acid, beta phenyl ethyl alcohol, diethyl malonate, caprylic acid, capric acid), by contraries to the wine obtained by the fermentation with other yeasts. Also the ethyl acetate is present in higher concentrations in the $T_{2}$ and $T_{3}$ wines, as a consequence of the higher biological activity of the yeast strains [20].

The strains $T_{1}, T_{4}, T_{5}$ and $T_{6}$, though are leading by fermentation to superior concentrations of the compounds mentioned before comparing to the control sample, produced also higher concentrations of acetic acid. These concentrations of acetic acid are similar with those determinated by classical titration method (see volatile acidity in Tab. I).

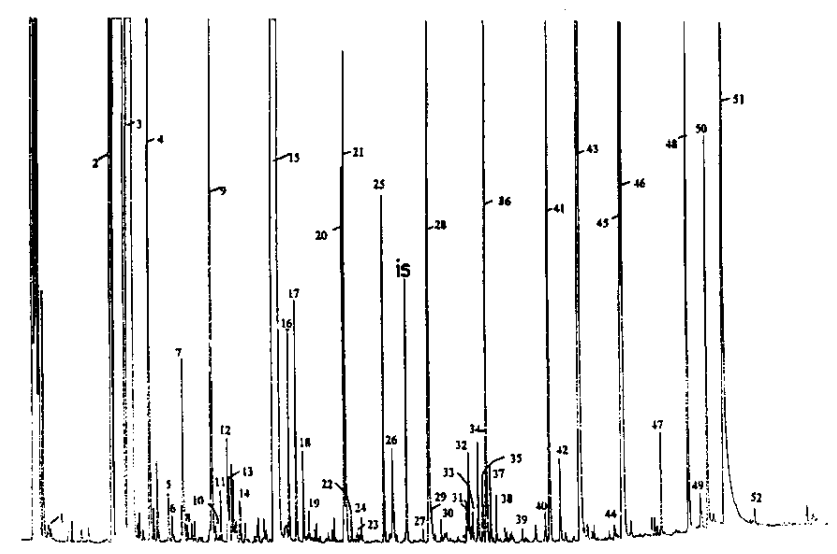

Fig. 1. Typical chromatogram of the volatile compounds isolated from wines obtained from the indigenous cultivar Feteasca Regalã. For peak identification see table II.
Among the identified compounds, delta 3-carene, camphor, iso-menthol and alpha terpineole are present as compounds originating in the grape aroma. Their concentration presents small variations, because the monoterpenes are not changed by the yeast metabolism during fermentation and this enables the characterization of wines made from different grape varieties [16]. Acetaldehyde could not be determinated due to its high volatility.

\section{Conclusions}

From the 6 selected strains, $T_{2}(S$. cerevisiae var. ellip soideus) and $T_{3}$ (S. carlsbergensis) proved to be especially valuable, this being validated by the chemical, chromatographic and organoleptic analysis. All these analyses confirmed that different strains from the same yeast family have the same fermentation metabolites, but in different concentrations.

The chromatographic analyses point out that Feteascã regalã cultivar has some specific aroma compounds resulted from the grapes. The main compounds issue from the fermentation where the two strains lead to the obtaining of wines of superior qualities comparing to the control sample. However, this that cannot put into value the authenticity of the cultivar in the specific conditions for the Panciu zone.

\section{References}

1. Blondin, B.; Vezinhet, F. Identification de souches de levures oenologiques par leurs caryotypes optenus en electrophorese en champ pulse; Rev. Fr. Oenol. 1988, 28, 7-11.

2. Carle, G. F.; Olson, M. V. An electrophoretic karyotype for yeast. Proc. Natl. Acad. Sci. 1985, 82, 3756-3760.

3. Coarer, M.; Poulard, A.; Daniel, P. Caractérisation des genres et espèces de levures oenologiques en champ pulse. Compte rendu I.T.V. Oenologie 1990, 1991; pp 165-166.

4. De la Calle Garcia, D.; Magnaghi, S.; Reichenbacher, M.; Danzer, K. HRC-J. High Resolut. Chromatog. 1996, 19(5), 257-262.

5. Etievant, P. X. Connaiss. Vigne Vin 1987, 21(4), 247-265.

6. Etievant, P. X.; Maarse, H.; Van den Berg, F. Chromatographia 1986, 21(7), 379-386.

7. Gassiot-Matas, M.; Comellas-Riera, L.; Rabada-Baiges, J. Afinidad 1983, 40(385), 207-212,

8. Gelsomini, N.; Capozzi, F.; Faggi, C.; J. High Resolut. Chromatogr. 1990, 13(5), 352-355,

9. Guntert, M.; Rapp, A.; Takeoka, G. R.; Jennings, W. Z. Lebensm. Unters Forsch. 1986, 182(3), 200-204.

10. Kallio, H. J. Chromatogr. Sci. 1991, 29(10), 438-443.

11. Lodder, J. The yeasts, a taxonomic study, North Holland Publising Company, Amsterdam, 1974.

12. Macici, M. The Romanian wines, Ed. Academiei, Bucuresti, 1990.

13. Noij, T.; Van-Es, A.; Cramers, C.; Rijks, J.; Dooper, R. J. High Resolut. Chromatogr. Chromatogr. Commun. 1987, 10(2), 6066.

14. Rapp, A. J. Anal. Chem. 1990, 337, 777-785.

15. Rapp, A.; McNamara, K.; Hoffman, A.; Proceedings of $18^{\text {th }}$ International Symposium on Capillary Chromatogr., Riva del Garda (Italy), 20-24 May, 1996. 
Table II. The main volatile compounds identified in wines with their Kovats retention time indices and the corresponding concentration (in $\mu \mathrm{g} / \mathrm{L}$ ).

\begin{tabular}{|c|c|c|c|c|c|c|c|c|c|}
\hline \multicolumn{2}{|r|}{ Compound } & \multicolumn{2}{|l|}{$\begin{array}{c}\text { Kovats } \\
\text { Retention }\end{array}$} & \multicolumn{6}{|c|}{$\begin{array}{l}\text { Compound concentration }(\mu g / L \text { or } p p b) \\
\text { Sample index }\end{array}$} \\
\hline No & Name & Indices & $T_{1}$ & $C$ & $T_{2}$ & $T_{3}$ & $T_{4}$ & $T_{5}$ & $T_{6}$ \\
\hline 1 & acetaldehyde & 703 & - & - & - & - & - & - & - \\
\hline 2 & ethyl acetate & 854 & 2270 & 2209 & 4270 & 4340 & 3153 & 4105 & 3757 \\
\hline 3 & ethanol & 908 & - & - & - & - & - & - & - \\
\hline 4 & 2-pentanone & 989 & 1791 & 1406 & 1931 & 1809 & 1237 & 1627 & 1590 \\
\hline 5 & delta-3-carene & 1036 & 86 & 102 & 122 & 111 & 92 & 114 & 108 \\
\hline 6 & ethyl butyrate & 1052 & 45 & 144 & 72 & 72 & 38 & 60 & 58 \\
\hline 7 & n-propanol & 1069 & 255 & 225 & 472 & 358 & 119 & 221 & 241 \\
\hline 8 & 2-methyl 3-buten-2-ol & 1075 & 54 & 43 & 65 & 67 & 38 & 41 & 50 \\
\hline 9 & iso-butanol & 1099 & 2704 & 1665 & 2677 & 3597 & 1569 & 3005 & 2056 \\
\hline 10 & tiglic aldehyde & 1104 & 8 & 10 & 30 & 28 & 21 & 26 & 26 \\
\hline 11 & 3-pentanol & 1120 & 76 & 75 & 98 & 84 & 111 & 73 & 76 \\
\hline 12 & 2-pentanol & 1135 & 173 & 178 & 217 & 183 & 279 & 164 & 167 \\
\hline 13 & isoamyl acetate & 1142 & 127 & 149 & 139 & 151 & 129 & 190 & 155 \\
\hline 14 & ethylbenzene & 1147 & 88 & 116 & 158 & 144 & 115 & 146 & 141 \\
\hline \multirow[t]{2}{*}{15} & 2-methyl and & & & & & & & & \\
\hline & 3-methyl iso-butanol & 1210 & 26393 & 18376 & 31724 & 33206 & 24117 & 30617 & 29454 \\
\hline 16 & ethyl caproate & 1239 & 292 & 325 & 387 & 358 & 248 & 128 & 341 \\
\hline 17 & n-amyl alcohol & 1259 & 414 & 370 & 462 & 412 & 399 & 369 & 369 \\
\hline 18 & styrene & 1273 & 113 & 140 & 166 & 149 & 123 & 153 & 150 \\
\hline 19 & n-butyl acetate & 1285 & 48 & 44 & 64 & 56 & 49 & 64 & 41 \\
\hline 20 & ethyl lactate & 1367 & 676 & 540 & 725 & 769 & 555 & 620 & 557 \\
\hline 21 & 1-hexanol & 1371 & 870 & 620 & 964 & 881 & 639 & 779 & 807 \\
\hline 22 & trans 3-hexen-1-ol & 1385 & 38 & 43 & 41 & 39 & 28 & 33 & 34 \\
\hline 23 & acetonyldimethylcarbinol & 1396 & 55 & 1024 & 31 & 146 & 31 & 981 & 186 \\
\hline 24 & cis 3-hexen-1-ol & 1404 & 64 & 54 & 59 & 52 & 43 & 48 & 50 \\
\hline 25 & ethyl caprylate & 1451 & 701 & 596 & 720 & 678 & 547 & 668 & 683 \\
\hline 26 & acetic acid & 1470 & 585 & 397 & 352 & 373 & 480 & 545 & 601 \\
\hline \multirow[t]{2}{*}{ IS } & 2-ethyl hexanol & & & & & & & & \\
\hline & (internal standard) & 1505 & - & - & - & - & - & - & - \\
\hline 27 & ethyl 3-hydroxybutyrate & 1542 & 24 & 20 & 23 & 27 & 18 & 14 & 16 \\
\hline 28 & camphor & 1560 & 2022 & 1947 & 2078 & 1966 & 1851 & 1984 & 2042 \\
\hline \multirow[t]{2}{*}{29} & ethyl 2-hydroxy & & & & & & & & \\
\hline & 4-methyl pentanoate & 1562 & 90 & 56 & 70 & 70 & 67 & 30 & 73 \\
\hline 30 & iso-butyric acid & 1587 & 73 & 49 & 48 & 63 & 36 & 37 & 42 \\
\hline 31 & n-butyric acid & 1661 & 96 & 98 & 89 & 89 & 47 & 51 & 54 \\
\hline 32 & ethyl decanoate & 1678 & 170 & 132 & 164 & 157 & 133 & 118 & 152 \\
\hline 33 & iso-menthol & 1684 & 84 & 79 & 73 & 71 & 73 & 70 & 70 \\
\hline 34 & gamma butyrolactone & 1690 & 210 & 189 & 244 & 295 & 139 & 177 & 259 \\
\hline 35 & iso-valeric acid & 1697 & 136 & 175 & 162 & 130 & 88 & 81 & 149 \\
\hline 36 & diethyl succinate & 1702 & 1296 & 1134 & 1281 & 917 & 840 & 955 & 1259 \\
\hline 37 & ethyl 9-decenoate & 1708 & 186 & 168 & 147 & 136 & 147 & 150 & 149 \\
\hline 38 & alpha-terpineole & 1716 & 95 & 83 & 117 & 92 & 91 & 75 & 87 \\
\hline 39 & ethyl 4-hydroxybutyrate & 1795 & 22 & 49 & 35 & 60 & 16 & 40 & 28 \\
\hline 40 & beta-phenethyl acetate & 1862 & 93 & 85 & 86 & 89 & 80 & 75 & 84 \\
\hline 41 & caproic acid & 1873 & 1640 & 1595 & 2060 & 2006 & 1318 & 1721 & 1629 \\
\hline 42 & $\begin{array}{l}\mathrm{N} \text {-(3-methylbutyl) } \\
\text { acetamide }\end{array}$ & 1890 & 144 & 136 & 199 & 192 & 135 & 116 & 129 \\
\hline 43 & $\begin{array}{l}\text { beta phenyl ethyl } \\
\text { alcohol }\end{array}$ & 1926 & 9139 & 6766 & 11263 & 11357 & 9354 & 8544 & 10742 \\
\hline 44 & iso-propyl myristate & 1964 & 24 & 22 & 36 & 25 & 25 & 23 & 23 \\
\hline 45 & diethyl malate & 2059 & 942 & 952 & 1202 & 1293 & 910 & 823 & 1036 \\
\hline 46 & caprylic acid & 2062 & 4460 & 4620 & 4687 & 4857 & 3606 & 4584 & 4207 \\
\hline \multirow[t]{2}{*}{47} & diethyl 2-hydroxy- & & & & & & & & \\
\hline & pentanedioate & 2115 & 160 & 201 & 212 & 254 & 149 & 161 & 232 \\
\hline 48 & capric acid & 2182 & 1300 & 1109 & 1383 & 1582 & 1046 & 1071 & 1174 \\
\hline \multirow[t]{2}{*}{49} & ethyl-2-hydroxy- & & & & & & & & \\
\hline & 3-phenylpropanoate & 2196 & 78 & 71 & 108 & 110 & 95 & 79 & 97 \\
\hline 50 & 9-decenoic acid & 2209 & 1010 & 1048 & 864 & 890 & 866 & 986 & 852 \\
\hline 51 & ethyl succinic acid & 2231 & 1813 & 1529 & 2464 & 1329 & 1433 & 1226 & 1983 \\
\hline 52 & ethyl oleate & 2305 & 45 & 48 & 54 & 64 & 27 & 87 & 38 \\
\hline
\end{tabular}


16. Rapp, A. Wine Analysis, Springer, Berlin, Chapter 3, 1988.

17. Sârghi, C.; Zironi, R. Aspecte inovative ale Enologiei moderne, Sigma, Chisinãu Eds., 1994; p 54.

18. Shimoda, M., Shibamoto, T., Noble, A.-C. J. Agric. Food Chem. 1993, 41(10), 1664-1668.

19. Takeoka, G.; Jennings, W. G. J. Chromatogr. Sci. 1984, 22(5), 177-184.
20. Usseglio-Tomasset, L. Chimie Oenologique. Technique et Documentation, Lavoisier, 1989; pp 244-247.

21. Uzochukwu, S. V. A.; Balogh, E.; Tucknot, O. G.; Lewis, M. J.; Ngoddy, P. O. J. Sci. Food Agric. 1994, 64(4), 405-411.

22. Vernin, G. Parfums, Cosmet Aromes 1986, 68, 83-90.

23. *** Recueil des méthodes internationales d'analyse des vins et des mouts, O.I.V., 1990. 